\title{
Synergistic Effect of Two Type Cellulase Immobilized on Chitosan Microparticle as Biocatalyst for Coconut Husk Hydrolysis
}

\author{
Afan Hamzah, Lidya Lorenta Sitompul, Irma Nurhanifah Fenda Putri, Soeprijanto, and Arief Widjaja \\ Department of Chemical Engineering, Institut Teknologi Sepuluh Nopember, Surabaya 60111, Indonesia
}

* Corresponding author:

tel: $+62-85231078200$

email:arief_w@chem-eng.its.ac.id

Received: August 3, 2018, 2018

Accepted: November 14, 2018

DOI: $10.22146 / \mathrm{ijc} .39714$

\begin{abstract}
The effectivity of employing two types of cellulases from Aspergillus niger and Trichoderma resei covalently immobilized on chitosan microparticle was investigated. Reducing sugar from CMC yielded by immobilized cellulase from T. resei alone and A. niger alone was $0.316 \mathrm{~g} / \mathrm{L}$ and $0.244 \mathrm{~g} / \mathrm{L}$, respectively. Simultaneous use of both cellulases shows a significant increase in reducing sugar produced to $1.020 \mathrm{~g} / \mathrm{L}$. The effective combination of this two types of cellulases also occurred when coconut husk was used as the substrate. A very high enzyme coupling of $92.06 \%$ compared to free enzyme was obtained in the immobilization. Addition of GDA not only increased enzyme coupling to 100\% but also improved sugar produced. Immobilized cellulase was successfully maintained its activity until 5 cycles.
\end{abstract}

Keywords: chitosan; cellulase; immobilization; microparticle; synergy; coconut husk

\section{- INTRODUCTION}

Endo-1,4- $\beta$-D-glucanase, exo-1,4- $\beta$-D-glucanase, and $1,4-\beta-\mathrm{D}$-glucosidase act synergistically to convert cellulose into sugar. These enzymes belong to a group of hydrolases known as cellulases [1-4]. The composition of the enzymes in cellulase is diverse based on a microorganism that produces it. Trichoderma resei produces more endo- $1,4-\beta-\mathrm{D}$-glucanase, exo-1,4- $\beta$-Dglucanase other than 1,4- $\beta$-D-glucosidase [5], while Aspergillus niger is known for its ability to produce $\beta$ glucosidase with significantly higher yields than Trichoderma species [6]. Combination work of the two kind cellulases will significantly increase the yield of reducing sugar.

However, cellulase has some obstacles in its application in producing reducing sugar, especially its susceptibility to inactivation, high cost and difficult to reuse. Immobilization of cellulase on the solid support can provide a technique to increase stability and reusability [7-8]. The support which had been reported to be used as enzyme carrier were $\mathrm{TiO}_{2}$ [9], polyurethane foam [10], entrapped in silica gel membrane [11], $\mathrm{MnO}_{2}$ [12], polyvinyl alcohol [13], chitosan [14], etc. Nevertheless, the mass transfer becomes the main obstacle since cellulose and immobilized enzyme are insoluble substrates. The micro-sized particle is believed to solve this obstacle due to its small size which is expected to reduce diffusion limitation [15-17].

Chitosan which is non-toxic, biocompatible and biodegradable has an advantage as immobilization support since it has numerous functional groups including amino, hydroxymethyl and hydroxyl group [15,18-19]. A covalent bond between the functional group of chitosan and amino acid of the enzyme will be formed [14]. Stability of immobilized enzyme can be enhanced by supplement of the crosslinker. Glutaral dialdehyde is the ideal cross-linking agent for its low price and has the ability to covalently bond with most of the enzymes [20].

Application of immobilized cellulase has been reported previously. However, most of the studies focused on the hydrolysis of commercial cellulose such as carboxymethylcellulose and microcrystalline cellulose and its chemical derivatives [14,18,21]. There are few studies of its utilization in insoluble lignocellulosic substrates such as straw cellulose [22], Agave atrovirens [23]. Lignocellulosic substrates consist of cellulose, hemicellulose, lignin and other substance that make them more complex and difficult to hydrolyze. There is

Afan Hamzah et al. 
no report for application on coconut husk. Coconut husks are treated as waste in Indonesia even though it contains $17.73 \%$ hemicellulose and $26.73 \%$ cellulose [24].

The objective of this study was to study the synergistic effect of cellulase from T. resei and cellulase from $A$. niger immobilized on chitosan microparticle and its application in the bioconversion of lignocellulosic biomass of coconut husk.

\section{- EXPERIMENTAL SECTION}

\section{Materials}

Coconut husk was obtained costless from a coir factory in South Minahasa, North Sulawesi, Indonesia. It was dried to reduce the water content and then milled and screened until the size of $100-120$ mesh. $\mathrm{NaOH} 1 \%(w / v)$ and coconut husk were heated at $80^{\circ} \mathrm{C}$ for $16 \mathrm{~h}$. Coconut husk was washed using hot distilled water and dried in an oven at $60{ }^{\circ} \mathrm{C}$ for $24 \mathrm{~h}$. Cellulase from $\mathrm{T}$ resei, cellulase from $A$ niger, magnetic particle $\left(\mathrm{Fe}_{3} \mathrm{O}_{4}\right)$ with $\pm 5 \mu \mathrm{m}$ diameter size, chitosan low molecular weight, 3,5dinitrosalicylic acid, sodium metabisulfite, sodium potassium tartrate, carboxymethyl cellulose, Coomassie brilliant blue (CBB) and bovine serum albumin (BSA) were purchased from Sigma-Aldrich. Glacial acetic acid, glucose, $\mathrm{Na}_{2} \mathrm{SO}_{4}, \mathrm{NaOH}, \mathrm{Na}_{2} \mathrm{HPO}_{4}, \mathrm{NaH}_{2} \mathrm{PO}_{4} \cdot 2 \mathrm{H}_{2} \mathrm{O}$ and Tween 80 were purchased from Merck.

\section{Procedure}

\section{Preparation of chitosan microparticle}

Chitosan magnetic microparticles were prepared using the method from Safarik et al. [15] with some modification. $4 \mathrm{~g}$ chitosan and $8 \mathrm{~g}$ magnetic particle were dissolved in $200 \mathrm{~mL}$ of $0.2 \mathrm{M}$ acetic acid. After thorough mixing, an excess of $1 \mathrm{M}$ sodium hydroxide was added to convert solubilized chitosan into insoluble chitosan. The chitosan containing entrapped magnetic microparticles was lyophilized and washed with water several times.

\section{Preparation of glutaric dialdehyde}

$0.1 \mathrm{~g}$ magnetic chitosan was added to $2.5 \%$ GDA solution in $100 \mathrm{~mL}$ phosphate buffer $\mathrm{pH} \mathrm{7,} \mathrm{kept} \mathrm{in} \mathrm{a}$ shaking incubator for $4 \mathrm{~h}$ at $25^{\circ} \mathrm{C}$ and left at that temperature for $12 \mathrm{~h}$ under static condition. Chitosan magnetic cross-linked with GDA was separated and rinsed with phosphate buffer $\mathrm{pH} 7$.

\section{Immobilization}

Covalent attachment method. The immobilization process used the method from Ghaffar et al. [14] with some modification. $0.1 \mathrm{~g}$ magnetic chitosan was added to each $T$ resei cellulase solution $((6,12,15$, or $18 \mathrm{mg}$ enzyme protein) in (phosphate buffer $\mathrm{pH} 7)$ ) and $A$ niger cellulase solution (best amount from T. resei). Amount of $A$ niger cellulase was kept constant at the same best amount of $T$ resei since this also resulted in the highest performance of hydrolysis. The immobilization process was executed in a shaking incubator for $24 \mathrm{~h}$ at $25^{\circ} \mathrm{C}$. The precipitates and the unbound enzyme was separated by washing with phosphate buffer and magnetic separation. The supernatants were used to determine the concentration of unbound protein. The immobilized enzymes were kept at $4{ }^{\circ} \mathrm{C}$. Immobilization yield was calculated as follows:

$\%$ immobilization yield $=\frac{\text { initial protein }- \text { unbound protein }}{\text { initial protein }} \times 100 \%$

Cross-linking method. Chitosan magnetic crosslinked with GDA $0.1 \mathrm{~g}$ were added to each enzyme (best concentration from $T$. resei), and the immobilization reaction was carried out same as the condition for covalent attachment method. The precipitates were separated using a magnet, and the unbound enzyme was eliminated by washing with phosphate buffer $\mathrm{pH}$ 7. The immobilized cellulase was stored at $4{ }^{\circ} \mathrm{C}$ until use.

\section{Enzymatic hydrolysis}

For CMC substrate, $0.1 \mathrm{~g}$ immobilized cellulase (chitosan+immobilized cellulase) under the varied $\mathrm{w} / \mathrm{w}$ ratio of $T$. resei and A. niger was added to $2 \mathrm{~mL} 1 \%$ carboxymethylcellulose (CMC) in citrate buffer $\mathrm{pH} 5.5$ and hydrolysis process was carried out for $1 \mathrm{~h}$ at $125 \mathrm{rpm}$ and $35^{\circ} \mathrm{C}$ [26]. The supernatant was analyzed for its reducing sugar content. For coconut husk as the substrate, $0.1 \mathrm{~g}$ immobilized cellulase was added to $1 \mathrm{~g}$ pre-treated coconut husk in $20 \mathrm{~mL}$ phosphate buffer $\mathrm{pH}$ 7 and hydrolysis process was executed for $48 \mathrm{~h}$ at $125 \mathrm{rpm}$ and $60^{\circ} \mathrm{C}$. The mixture was centrifuged $\left(10,000 \mathrm{rpm}, 4^{\circ} \mathrm{C}\right)$ and the liquid of it will be analyzed for its reducing sugar 
content. The specific activity of free cellulase from $A$ niger and $T$ resei was 12.6 and $4.38 \mathrm{U} / \mathrm{mg}$, respectively. Based on this data, the combination of these two cellulases was conducted based on the amount of protein rather than the activity in order to ease the procedure.

\section{Reusability study}

$0.1 \mathrm{~g}$ immobilized cellulase was utilized to hydrolyze $1 \mathrm{~g}$ pre-treated coconut husk in $20 \mathrm{~mL}$ phosphate buffer $\mathrm{pH} 7$ at $60{ }^{\circ} \mathrm{C} 48 \mathrm{~h}$. After separation by a magnet, the immobilized cellulase was rinsed with phosphate buffer $\mathrm{pH} 7$, and it was suspended again in a fresh reaction mixture. The reusability study was studied until 5 cycles. The glucose productivity during $48 \mathrm{~h}$ was used to evaluate the reusability of the enzyme.

\section{Analytical method}

The morphology and size of chitosan microparticle were examined using SEM (Scanning electron microscopy) (inspect s50, Netherland). The protein content of enzyme before immobilization and its supernatant after immobilization was analyzed by Bradford method using bovine serum albumin as a standard solution [27]. The activities of cellulase were determined by measuring the amount of reducing sugars produced detected by 5dinitrosalicylic acid (DNS) during enzymatic hydrolysis of carboxymethyl cellulose (CMC). Reducing sugar was determined by DNS analysis to obtain the concentration of reducing sugar [28]. FT-IR spectra were measured using FT-IR spectrometer (Thermo scientific, US).

\section{- RESULTS AND DISCUSSION}

\section{Size and Structure of Chitosan Microparticle}

Chitosan microparticles were prepared by using precipitation method from Biro et al. and Safarik et al. $[15,25]$ with some modification. The main principle of this method is exploiting the solubility of chitosan which is affected by its $\mathrm{pH}$. The amino group of chitosan has a pKa value of 6.5. This means that chitosan is soluble in an acid solution [18,29]. Addition of acetic acid stimulated the protonation of the amino groups to lead to improvement of chitosan solubility [30]. $\mathrm{NaOH}$ was added to increase the $\mathrm{pH}$ of the solution. The increasing of $\mathrm{pH}$ will form insoluble chitosan microparticles [25].

Fig. 1 shows the SEM micrographs of chitosan magnetic microparticle obtained in the present work. Microparticles mostly have an irregular shape with diameter vary between $305.1-815 \mu \mathrm{m}$ and pore size vary between 206.1-1.733 $\mu \mathrm{m}$ as determined in the program of SEM instrument (FEI Inspect S50).

\section{Immobilization}

Cellulase can be immobilized directly to chitosan by covalent attachment method. It can be seen from Fig. 2(a) that chitosan has amino groups, cellulase has carboxylic groups, and GDA has aldehyde groups which are made all of them highly reactive and can form covalent bond with each other, in which the free amino groups $\left(-\mathrm{NH}_{2}\right)$ of chitosan are bonded directly to the carboxylic terminal residue in the enzymes [14,31]. Cellulase was also immobilized by combining crosslinking and covalent attachment method shown in Fig. 2(b). The amino groups in chitosan were reacted with Glutaral dialdehyde (GDA) as a cross-linking agent, and then cellulase was attached to them [14,32-33].

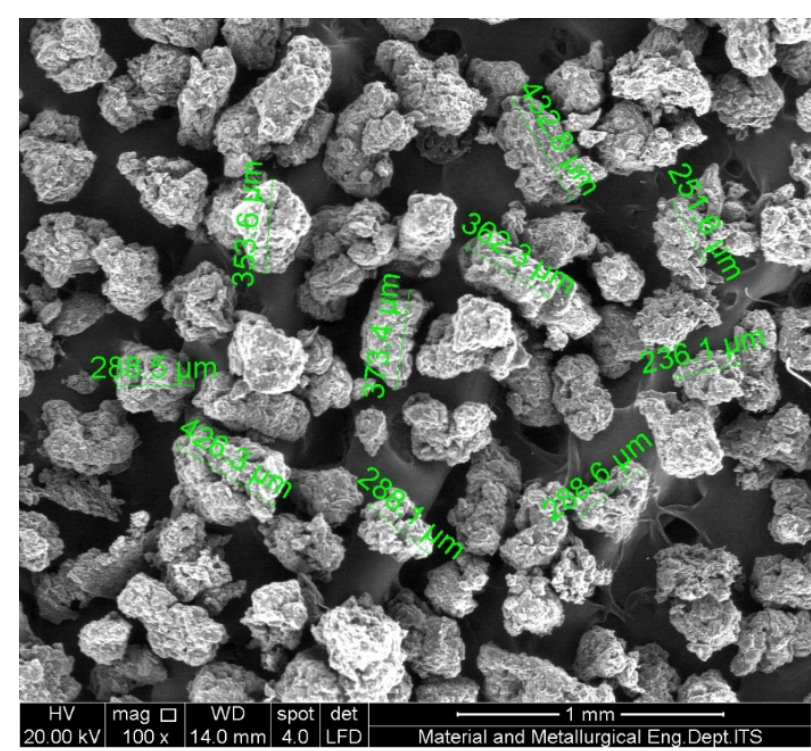

Fig 1. SEM micrographs chitosan microparticle 
(a)
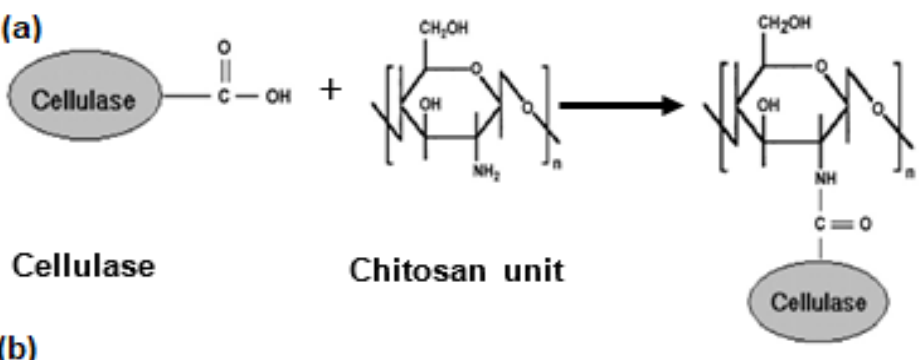

(b)

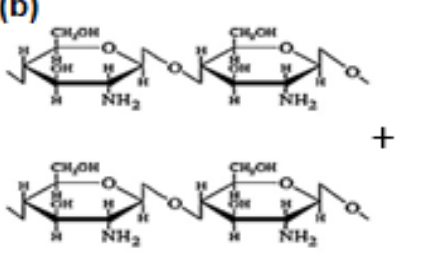

Chitosan

GDA

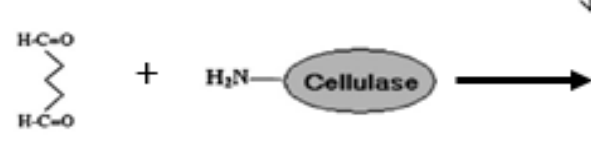

Cellulase

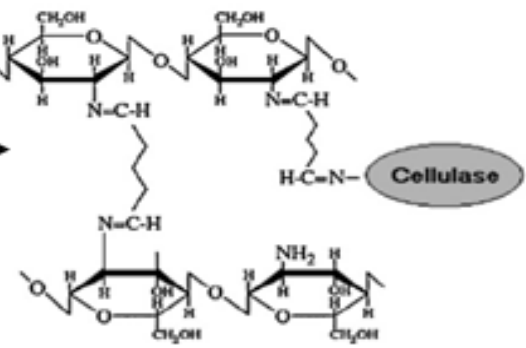

Fig 2. (a) Covalent attachment mechanism between chitosan and cellulase (b) Mechanism of cellulase immobilized on chitosan cross-linked with GDA [14]

The reaction between chitosan and cellulose was confirmed by FT-IR spectra. The spectra of chitosan and immobilized cellulase on chitosan are shown in Fig. 3. From the figure, there were significant changes of the peak in 3272.53, 1632.67, and $1080 \mathrm{~cm}^{-1}$, that is the characteristic of the amino group $(\mathrm{N}-\mathrm{H}), \mathrm{C}=\mathrm{O}$, and (aliphatic amide) C-N, respectively [34]. Fig. 3 also shows FT-IR spectra for chitosan-GDA and cellulase immobilized on chitosan-GDA. It can be seen from this figure that there has been a peak at $1633 \mathrm{~cm}^{-1}$ which can be associated to the $\mathrm{C}=\mathrm{N}$ for chitosan with a glutaric dialdehyde.

Cellulase was immobilized to $0.1 \mathrm{~g}$ chitosan microparticle for an incubation time of $24 \mathrm{~h}$. Optimum enzyme coupling was investigated using cellulase from $T$. resei. From Table 1, an optimum enzyme coupling per 0.1 g chitosan with $92 \%$ retained enzyme was obtained using $6 \mathrm{mg}$ protein enzyme. These values are higher than those reported by Xu et al. (40\%) [35] and Sanchez-Ramirez et al. (66.7\%) [23]. Both of them using chitosan magnetic nanoparticle as support. Protein less than $6 \mathrm{mg}$ was not investigated because the added volume of the enzyme would not be enough to provide good contact between enzyme and support. Chitosan magnetic microparticle crossed-linked with $2.5 \%$ GDA resulted in $100 \%$ retained enzyme. From the table also shows that the percentage of enzyme immobilized declined even though more of free- enzyme was added. This may occur due to the support steric hindrance of the active site and multipoint attachment between cellulase to the chitosan that results on less enzyme coupled [35-36].

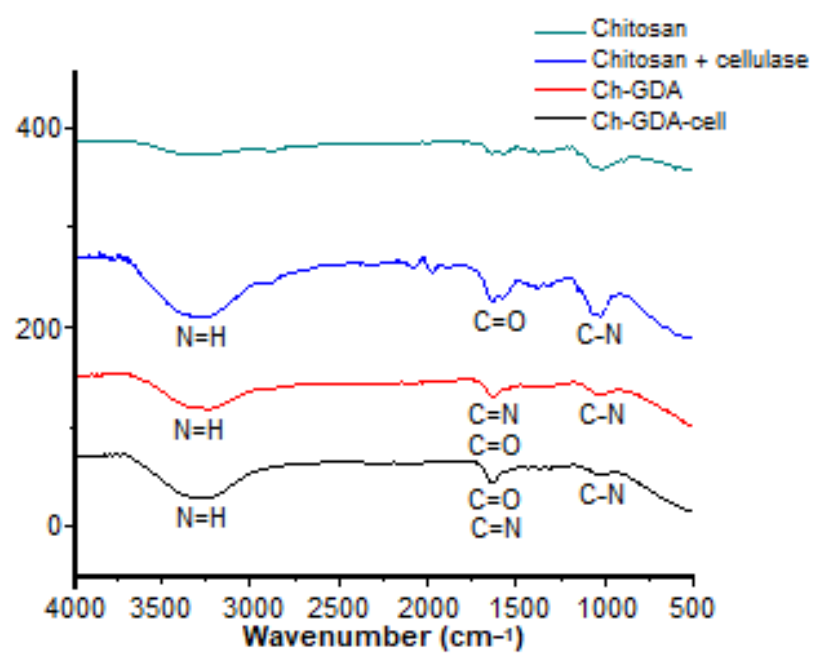

Fig 3. FT-IR spectra of cellulase immobilization

Table 1. Cellulase from T. reesei coupling on chitosan microparticle

\begin{tabular}{cll}
\hline \multirow{2}{*}{$\begin{array}{c}\text { Cellulase } \\
(\mathrm{mg})\end{array}$} & \multicolumn{2}{l}{ Immobilized cellulase } \\
\cline { 2 - 3 }$(\mathrm{mg})$ & $(\%)$ \\
\hline 6 & 5.556 & 92.60 \\
9 & 8.200 & 91.12 \\
12 & 10.934 & 91.12 \\
15 & 12.544 & 83.63 \\
18 & 14.981 & 83.23 \\
\hline
\end{tabular}


Table 2. Reducing sugar produced from CMC by immobilized cellulase

\begin{tabular}{cccc}
\hline $\begin{array}{l}\text { Immobilized Cellulase } \\
\text { from A. niger }(\mathrm{mg})\end{array}$ & $\begin{array}{l}\text { Immobilized Cellulase } \\
\text { from T. resei }(\mathrm{mg})\end{array}$ & $\begin{array}{l}\text { The ratio of } \\
\text { An:Tr }(\mathrm{w} / \mathrm{w})\end{array}$ & $\begin{array}{l}\text { Reducing } \\
\text { sugar }(\mathrm{g} / \mathrm{L})\end{array}$ \\
\hline 6 & 0 & $1: 0$ & 0.244 \\
0 & 6 & $0: 1$ & 0.316 \\
2 & 4 & $1: 2$ & 1.020 \\
4 & 2 & $2: 1$ & 0.906 \\
3 & 3 & $1: 1$ & 0.942 \\
\hline
\end{tabular}

${ }^{\star}$ Specific activity of free cellulase from A. niger and T. resei were $12.6 \mathrm{IU} / \mathrm{mg}$ and $4.388 \mathrm{IU} / \mathrm{mg}$, respectively

\section{Hydrolysis}

\section{CMC substrate}

The synergistic work of cellulase from A. niger and cellulase from $T$. resei was investigated using $\mathrm{CMC}$ as a substrate. The total amount of cellulase was set to $6 \mathrm{mg}$ protein according to the result in Table 1 . Table 2 shows the result of CMC hydrolysis catalyzed by cellulase immobilized on chitosan microparticle. The table shows that reducing sugar produced by immobilized A. niger cellulase alone and T. resei cellulase alone were less than reducing sugar produced by a combination of both cellulases. A. niger cellulase to T. resei cellulase ratio of 1:2 $(\mathrm{w} / \mathrm{w})$ resulted in the highest reducing sugar of $1.02 \mathrm{~g} / \mathrm{L}$. This outcome proved the synergistic work of the two cellulases to produce reducing sugar.

\section{Coconut husk substrate}

Coconut husk comprised of $26.72 \%$ cellulose and $17.73 \%$ hemicellulose [37] which is able to be converted to reducing sugar. In this hydrolysis process, the 1:2 (w/w) ratio of $A$. niger: $T$. resei of immobilized cellulase was used. The effect of chitosan cross-linked to Glutaral dialdehyde (GDA) (2.5\%) was also investigated. Fig. 4 shows the time course of reducing sugar produced by the immobilized enzyme. In line to the result using CMC as the substrate, the sugar produced from coconut husk using immobilized cellulase from single fungus was much less than that using immobilized cellulase from $A$. niger and T. resei applied together. Sugar concentration of 0.507 and $0.683 \mathrm{~g} / \mathrm{L}$ were obtained using chitosan and chitosanGDA, respectively after $48 \mathrm{~h}$. Addition of GDA makes the amino groups of chitosan were activated, the amount of enzyme coupled improved [38]. The cross-linker (GDA)

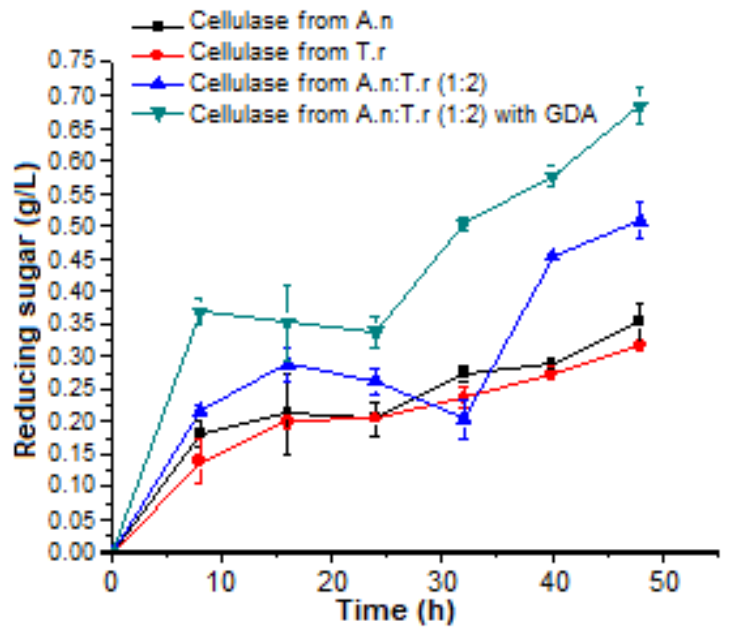

Fig 4. Time course of reducing sugar produced by hydrolysis of coconut husk.

may act as a spacer arm between the cellulose and chitosan which decreases the steric hindrance [14]. The sugar concentration shown in Fig. 4 did not seem to be a maximum since the curve still showed an increasing trend with increasing reaction time. It can be seen that the concentration of reducing sugar was lower than that obtained using CMC as the substrate. It may indicate the existence of a significant mass transfer resistance between immobilized cellulase and coconut husk both of which are insoluble compound.

\section{Reusability Study}

Fig. 5 shows the result of reusability study of the immobilized cellulase with and without GDA. The figure shows that the immobilized cellulase preserved its activity after five cycles. The immobilized cellulase on chitosan and chitosan cross-linked with GDA retained 98.15 and $82.74 \%$ of its initial activity, respectively. 

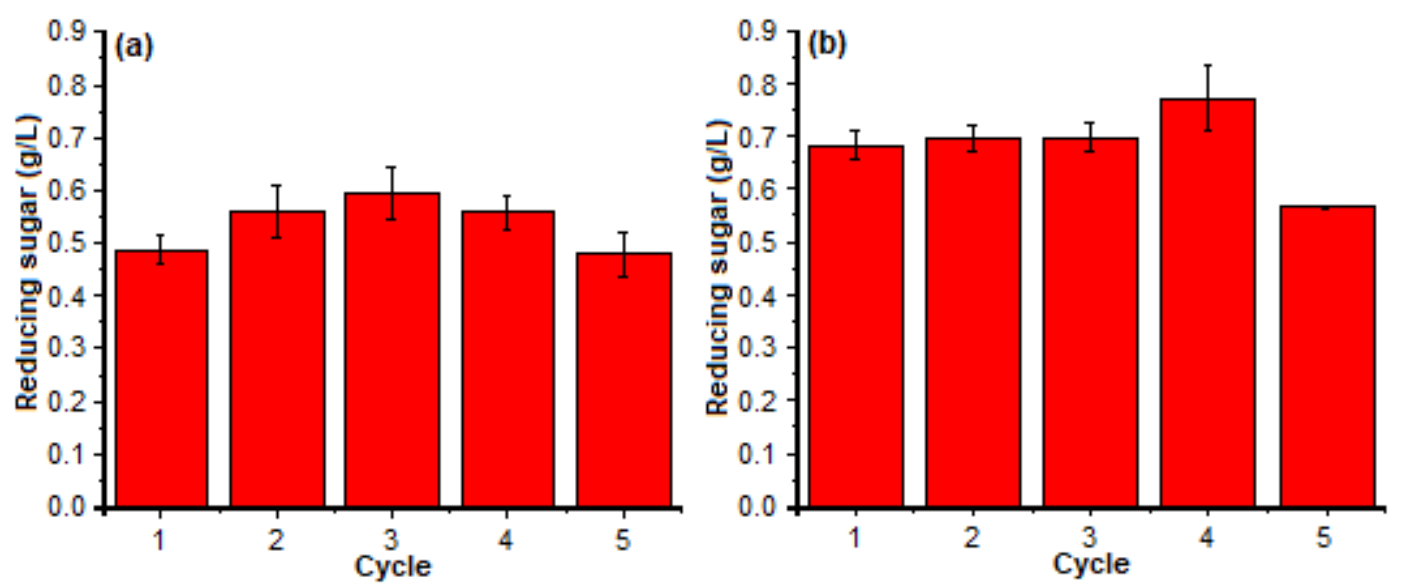

Fig 5. Reducing sugar production in different cycles of hydrolysis of coconut husk with two type of cellulase immobilized on (a) chitosan magnetic and (b) chitosan magnetic-GDA

Utilization of GDA as cross-linking agent improved reducing sugar production since GDA acts as spacer arm between enzyme and support resulting in more enzyme coupled on support. However, an immobilized enzyme on chitosan-GDA gave lesser productivity than without GDA. It may due to loss of enzyme activity. This activity loss might due to the small size of cross-linker which is easily penetrated to into the active site and cross-links with catalytically important amino acids residues [20]. It is encouraging to see from both figures that immobilized cellulase can be reused until five cycles without losing its catalytic activity. The figures also show that the addition of $2.5 \%$ GDA to chitosan matrix increased the sugar produced by the hydrolysis. This outcome is competitive with the previous result by Viera et al. [39] which immobilized $\beta$-galactosidase on the chitosan-based matrix and maintained its activity after 4 cycles. SanchezRamirez et al. [23] reported that reusability of cellulase immobilized on chitosan magnetic nanoparticles was done in five cycles of agave fibers hydrolysis with maintaining of $50 \%$ of the initial activity.

\section{- CONCLUSION}

Two types of cellulases from T. resei and A. niger were successfully immobilized on chitosan microparticle prepared by precipitation method. The FT-IR spectra confirmed the formation of covalent attachment between the enzyme and the support as well as the existence of cross-linking by GDA. The use of cellulase from A. niger and cellulase from $T$. resei in the same time under optimum ratio significantly increased the yield of sugar. The immobilized cellulase prepared by the method can be reused for several times without losing any of its activity. Synergistic work of two type cellulase covalently immobilized on chitosan magnetic microparticle has potential and economic benefit for converting lignocellulose to reducing sugar.

\section{- ACKNOWLEDGMENTS}

The authors are grateful to the Directorate General of Resources for science, Technology, and Higher education, Ministry of Research, Technology and Higher Education of Republic Indonesia to give funding for this study under a scheme (135/SP2H/LT/DRPM/ IV/2017) called "(PMDSU)”.

\section{- REFERENCES}

[1] Li, C., Yoshimoto, M., Fukunaga, K., and Nakao, K., 2007, Characterization and immobilization of liposome-bound cellulase for hydrolysis of insoluble cellulose, Bioresour. Technol., 98 (7), 1366-1372.

[2] Ahamed, A., and Vermette, P., 2008, Enhanced enzyme production from mixed cultures of Trichoderma reesei RUT-C30 and Aspergillus niger LMA grown as fed batch in a stirred tank bioreactor, Biochem. Eng. J., 42 (1), 41-46.

[3] Martins, L.F., Kolling, D., Camassola, M., Dillon, A.J.P., and Ramos, L.P., 2008, Comparison of 
Penicillium echinulatum and Trichoderma reesei cellulases in relation to their activity against various cellulosic substrates, Bioresour. Technol., 99 (5), 1417-1424.

[4] Ungurean, M., Paul, C., and Peter, F., 2013, Cellulase immobilized by sol-gel entrapment for efficient hydrolysis of cellulose, Bioprocess Biosyst. Eng., 36 (10), 1327-1338.

[5] Stockton, B.C., Mitchell, D.J., Grohmann, K., and Himmel, M.E., 1991, Optimum $\beta$-D-glucosidase supplementation of cellulase for efficient conversion of cellulose to glucose, Biotechnol. Lett., 13 (1), 57-62.

[6] Juhász, T., Kozma, K., Szengyel, Z., and Réczey, K., 2003, Production of $\beta$-glucosidase in mixed culture of Aspergillus niger BKMF 1305 and Trichoderma reesei RUT C30, Food Technol. Biotechnol., 41 (1), 49-53.

[7] Liu, J., and Cao, X., 2013, Biodegradation of microcrystalline cellulose in $\mathrm{pH}-\mathrm{pH}$ recyclable aqueous two-phase systems with water-soluble immobilized cellulase, Biochem. Eng. J., 79, 136-143.

[8] Cheng, C., and Chang, K.C., 2013, Development of immobilized cellulase through functionalized gold nano-particles for glucose production by continuous hydrolysis of waste bamboo chopsticks, Enzyme Microb. Technol., 53 (6-7), 444-451.

[9] Ahmad, R., and Sardar, M., 2014, Immobilization of cellulase on $\mathrm{TiO}_{2}$ nanoparticles by physical and covalent methods: A comparative study, Indian J. Biochem. Biophys., 51 (4), 314-320.

[10] Chakrabarti, A.C., and Storey, K.B., 1988, Immobilization of cellulase using polyurethane foam, Appl. Biochem. Biotechnol., 19 (2), 189-207.

[11] Nguyen, L.T., Neo, K.R.S., and Yang, K.L., 2015, Continuous hydrolysis of carboxymethyl cellulose with cellulase aggregates trapped inside membranes, Enzyme Microb. Technol., 78, 34-39.

[12] Cherian, E., Dharmendirakumar, M., and Baskar, G., 2015, Immobilization of cellulase onto $\mathrm{MnO}_{2}$ nanoparticles for bioethanol production by enhanced hydrolysis of agricultural waste, Chin. J. Catal., 36 (8), 1223-1229.
[13] Liao, H., Chen, D., Yuan, L., Zheng, M., Zhu, Y., and Liu, X., 2010, Immobilized cellulase by polyvinyl alcohol/ $/ \mathrm{Fe}_{2} \mathrm{O}_{3}$ magnetic nanoparticle to degrade microcrystalline cellulose, Carbohydr. Polym., 82 (3), 600-604.

[14] El-Ghaffar, M.A.A., and Hashem, M.S., 2010, Chitosan and its amino acids condensation adducts as reactive natural polymer supports for cellulase immobilization, Carbohydr. Polym., 81 (3), 507-516.

[15] Biró, E., Németh, A.S., Sisak, C., Feczkó, T., and Gyenis, J., 2008, Preparation of chitosan particles suitable for enzyme immobilization, J. Biochem. Biophys. Methods, 70 (6), 1240-1246.

[16] Budriene, S., Gorochovceva, N., Romaskevic, T., Yugova, L.V., Miezeliene, A., Dienys, G., and Zubriene, A., 2005, $\beta$-Galactosidase from Penicillium canescens. Properties and immobilization, Cent. Eur. J. Chem., 3 (1), 95-105.

[17] Zheng, Y.G., Chen, X.L., and Wang, Z., 2005, Microbial biomass production from rice straw hydrolysate in airlift bioreactors., J. Biotechnol., 118 (4), 413-420.

[18] Zang, L., Qiu, J., Wu, X., Zhang, W., Sakai, E., and Wei, Y., 2014, Preparation of magnetic chitosan nanoparticles as support for cellulase immobilization, Ind. Eng. Chem. Res., 53 (9), 3448-3454.

[19] Mao, X., Guo, G., Huang, J., Du, Z., Huang, Z., Ma, L., Li, P., and Gu, L., 2006, A novel method to prepare chitosan powder and its application in cellulase immobilization, J. Chem. Technol. Biotechnol., 81, 189-195.

[20] Sojitra, U.V., Nadar, S.S., and Rathod, V.K., 2017, Immobilization of pectinase onto chitosan magnetic nanoparticles by macromolecular crosslinker, Carbohydr. Polym., 157, 677-685.

[21] Alftrén, J., and Hobley, T.J., 2014, Immobilization of cellulase mixtures on magnetic particles for hydrolysis of lignocellulose and ease of recycling, Biomass Bioenergy, 65, 72-78.

[22] Zheng, P., Wang, J., Lu, C., Xu, Y., and Sun, Z., 2013, Immobilized $\beta$-glucosidase on magnetic chitosan microspheres for hydrolysis of straw 
cellulose, Process Biochem., 48 (4), 683-687.

[23] Sanchez-Ramirez, J., Martinez-Hernandez, J.L., Segura-Ceniceros, P., Lopez, G., Saade, H., MedinaMorales, M.A., Ramos-Gonzalez, R., Aguilar, C.N., and Ilyina, A., 2017, Cellulases immobilization on chitosan-coated magnetic nanoparticles: Application for Agave atrovirens lignocellulosic biomass hydrolysis, Bioprocess Biosyst. Eng., 40 (1), 9-22.

[24] Sangian, H.F., Kristian, J., Rahma, S., Agnesty, S.Y., Gunawan, S., and Widjaja, A., 2015, Comparative Study of the preparation of reducing sugars hydrolyzed from high-lignin lignocellulose pretreated with ionic liquid, alkaline solution and their combination, J. Eng. Technol. Sci., 47 (2), 137-148.

[25] Safarik, I., Horska, K., Pospiskova, K., and Safarikova, M., 2012, One-step preparation of magnetically responsive materials from nonmagnetic powders, Powder Technol., 229, 285-289.

[26] Anwar, N., Widjaja, A., and Winardi, S., 2012, Study of the enzymatic hydrolysis of alkaline-pretreated rice straw using cellulase of various sources and compositions, Int. Rev. Biophys. Chem., 3 (1), 272278.

[27] Bradford, M.M., 1976, A rapid and sensitive method for the quantitation of microgram quantities of protein utilizing the principle of protein-dye binding, Anal. Biochem., 72 (1-2), 248-254.

[28] Miller, G.L., 1959, Use of Dinitrosalicylic acid reagent for determination of reducing sugar, Anal. Chem., 31 (3), 426-428.

[29] Wang, J., Zhao, G., Li, Y., Liu, X., and Hou, P., 2013, Reversible immobilization of glucoamylase onto magnetic chitosan nanocarriers, Appl. Microbiol. Biotechnol., 97 (2), 681-692.

[30] Al-Remawi, M.M.A., 2012, Properties of chitosan nanoparticles formed using sulfate anions as crosslinking bridges, Am. J. Appl. Sci., 9 (7), 10911100.

[31] Abdel-Naby, M.A., Ismail, A.M.S., Abdel-Fattah, A.M., and Abdel-Fattah, A.F., 1999, Preparation and some properties of immobilized Penicillium funiculosum 258 dextranase, Process Biochem., 34 (4), 391-398.

[32] Chang, M.Y., and Juang, R.S., 2005, Activities, stabilities, and reaction kinetics of three free and chitosan-clay composite immobilized enzymes, Enzyme Microb. Technol., 36 (1), 75-82.

[33] Çetinus, Ş.A., and Öztop, H.N., 2003, Immobilization of catalase into chemically crosslinked chitosan beads, Enzyme Microb. Technol., 32 (7), 889-894.

[34] Mistry, B.D., 2009, A Handbook of Spectroscopic Data: UV, IR, PMR, CNMR and Mass Spectroscopy, Oxford Book Company.

[35] Xu, J., Huo, S., Yuan, Z., Zhang, Y., Xu, H., Guo, Y., Liang, C., and Zhuang, X., 2011, Characterization of direct cellulase immobilization with superparamagnetic nanoparticles, Biocatal. Biotransform., 29 (2-3), 71-76.

[36] Jordan, J., Kumar, C.S.S.R., and Theegala, C., 2011, Preparation and characterization of cellulasebound magnetite nanoparticles, J. Mol. Catal. B: Enzym., 68 (2), 139-146.

[37] Sangian, H.F., Ranggina, D., Ginting, G.M., Purba, A.A., Gunawan, S., and Widjaja, A., 2015, Study of the preparation of sugar from high-lignin lignocellulose applying subcritical water and enzymatic hydrolysis: Synthesis and consumable cost evaluation, St. Cerc. St. CICBIA, 16, 13-27.

[38] Chen, H., Zhang, Q., Dang, Y., and Shu, G., 2013, The Effect of glutaraldehyde cross-linking on the enzyme activity of immobilized $\beta$-galactosidase on chitosan bead, Adv. J. Food Sci. Technol., 5 (7), 932935.

[39] Vieira, D.C., Lima, L.N., Mendes, A.A., Adriano, W.S., Giordano, R.C., Giordano, R.L.C., and Tardioli, P.W., 2013, Hydrolysis of lactose in whole milk catalyzed by $\beta$-galactosidase from Kluyveromyces fragilis immobilized on chitosanbased matrix, Biochem. Eng. J., 81, 54-64. 